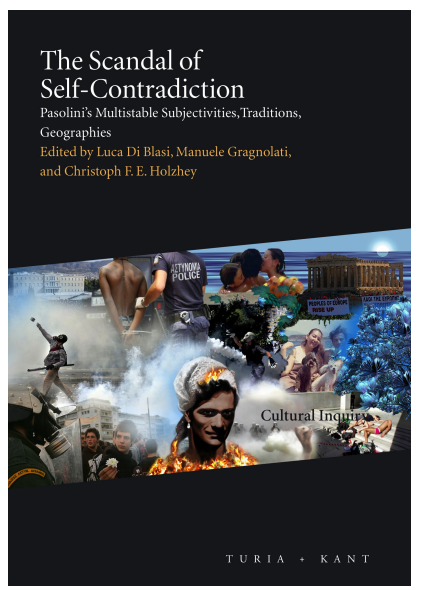

The Scandal of Self-Contradiction: Pasolini's Multistable Subjectivities, Geographies, Traditions, ed. by Luca Di Blasi, Manuele Gragnolati, and Christoph F. E. Holzhey, Cultural Inquiry, 6 (Vienna: Turia + Kant, 2012), pp. 119-33

PREVIOUSLY PUBLISHED AS:

| Identical except for DOI prefix 10.25620

\section{MANUELE GRAGNOLATI \\ Analogy and Difference \\ Multistable Figures in Pier Paolo Pasolini's Appunti per un'Orestiade Africana}

CITE AS:

\begin{abstract}
Manuele Gragnolati, 'Analogy and Difference: Multistable Figures in Pier Paolo Pasolini's Appunti per un'Orestiade Africana', in The Scandal of Self-Contradiction: Pasolini's Multistable Subjectivities, Geographies, Traditions, ed. by Luca Di Blasi, Manuele Gragnolati, and Christoph F. E. Holzhey, Cultural Inquiry, 6 (Vienna: Turia + Kant, 2012), pp. 119-33 <https://doi.org/10.37050/ci-06_07>
\end{abstract}

RIGHTS STATEMENT:

(C) by the author(s)

This version is licensed under a Creative Commons AttributionShareAlike 4.0 International License.

ABSTRACT: My paper will discuss Pasolini's preference for the figure of contradiction and his opposition to Hegelian dialectics, as he understood it, from the perspective of multistable figures or Kippbilder. A Kippbild is a figure that oscillates between distinct aspects without mediation or synthesis. My basic questions are whether it is possible to read Pasolini's insistence on contradictions in terms of multistable figures and what might be gained from such a reading. 


\title{
ANALOGY AND DIFFERENCE
}

\author{
Multistable Figures in Pasolini's \\ Appunti per un'Orestiade africana
}

Manuele Gragnolati

'Lo scandalo del contraddirmi, dell'essere / con te e contro te; con te nel cuore / in luce, contro te nelle buie viscere. ${ }^{1}$ From Franco Fortini's concept of sineciosi to Hervé Joubert-Laurencin's notion of amphibology, critics have higlighted Pier Paolo Pasolini's fascination with, and performance of, the figure of contradiction. ${ }^{2}$ In the case of the lines just cited from the Ceneri di Gramsci, which are often quoted as the blueprint of Pasolini's poetics, the contradiction lies between reason and 'guts' (viscere), between Marxist convictions and aesthetic fantasies. Phrases like 'passione e ideologia', 'transumanar e organizzar', 'disperata vitalità', and 'tetro entusiasmo' indicate the extent to which Pasolini made contradiction the cipher for his own subjectivity and poetics. ${ }^{3}$

By insisting on contradiction, Pasolini also refutes any sense of development towards synthesis or resolution, which he often identifies with Hegelian dialectics. Several works selected for the seminar 'Jenseits Europas: Pasolini und das abendländische Erbe' and now explored in this volume deal with this question. It is addressed most directly in Medea and San Paolo; but Pasolini also refers to it in a statement made in 1971 and reported by Sergio Arecco, as well as in Il sogno del centauro, his interview with Jean Duflot:

Da cosa nasce la 'speranza', quella della prassi marxista e quella della pragmatica borghese? Nasce da una comune matrice: Hegel. Io sono contro Hegel (esistenzialmente - empirismo eretico). Tesi? Antitesi? Sintesi? Mi sembra troppo comodo. La mia dialettica non [è] più ternaria ma binaria. Ci sono solo opposizioni, inconciliabili. ${ }^{4}$

Hegel! Sade! Il mito! Eh già! Quando parlo della natura bisogna sempre intendere 'mito della natura': mito antihegeliano e antidialettico, perché la natura non conosce i 'superamenti'. Ogni cosa in essa si giustappone e coesiste $[\ldots]$. In quanto 'storicista', capisco che la storia è una evoluzione, un continuo superamento dei dati; sono altrettanto consapevole però che tali dati non vengono mai eliminati, ma sono permanenti. Sarà irrazionale, ma è $\operatorname{cosi}^{5}$ 


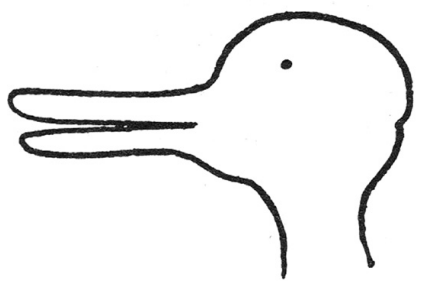

Fig. 1. Ludwig Wittgenstein's 'Duck-Rabbit'

My paper will discuss Pasolini's preference for the figure of contradiction and his opposition to Hegelian dialectics, as he understood it, from the perspective of multistable figures or Kippbilder. A Kippbild is a figure that oscillates between distinct aspects without mediation or synthesis. A famous example is the 'duck-rabbit' image that Ludwig Wittgenstein discusses in his Philosophical Investigations (Fig. 1). ${ }^{6}$ The image can be seen as a duck or as a rabbit; the two statements 'It's a duck' 'It's a rabbit' seem to stand in contradiction, and the assertion that it is both at the same time appears paradoxical. While one can easily go back and forth between the two aspects, the contradiction seems irresolvable; no mediation, synthesis, or dialectical progress seems possible. One sees either the duck or the rabbit, but not both at the same time. Yet the image cannot be reduced to one or the other: it is neither (only) a duck nor (only) a rabbit, but both a duck and a rabbit. The combination of simultaneity (the coexistence of several aspects in one image) and consecutiveness (the change from one aspect to another) yields both either/or and bothland. The shift from one aspect to the other, from seeing a duck to seeing a rabbit and vice versa, which Wittgenstein calls Aspektwechsel (aspect-change), also points to the activity of the perceiving subject. Multistable figures thereby allow the subject to experience his or her own active role in perception and to become aware of it. ${ }^{7}$

My basic questions are whether it is possible to read Pasolini's insistence on contradictions in terms of multistable figures and what might be gained from such a reading. In particular, focussing on the movie Appunti per un'Orestiade africana, I am interested in exploring how the Kippbild, which shifts constantly from one aspect to the other, relates to Pasolini's stance against reason and progress as well as what it can say about the relationship between 'other' and ' $I$ ' in the different figurations that it takes in this movie: bourgeois versus sub-proletarian; 
Western versus African; past versus present; political engagement and progressive ideology versus (irrational) attachment to the past.

Pasolini's engagement with Aeschylus began in 1959, when he was asked to translate the Oresteia from ancient Greek into Italian for a production of the play in Syracuse. ${ }^{8}$ In 1966 he also began to write the play Pilade, which invents a continuation of the Oresteia (and which is analyzed by Christoph Holzhey in this volume). Appunti per un'Orestiade Africana was shot and edited between 1968 and 1970 and shown in 1973, but released only after Pasolini's death in 1975. It takes the form of a project or notes for a movie that would transpose Aeschylus's trilogy from ancient Greece to contemporary Africa, and it assembles different kinds of materials: documentary footage shot by Pasolini in Tanzania and Uganda, with Pasolini's voice-over commenting upon the images; archive footage from the Biafran civil wars, which Pasolini imagines could represent the Trojan war; an interview with some African students at the University of Rome; a jazz session in a studio in Rome with two African-American singers performing the scene of Cassandra's dream from the Agamemnon, the first play in Aeschylus's trilogy.

As Pasolini acknowledges in a 1968 interview with Lino Peroni concerning a larger project entitled Appunti per un poema sul Terzo Mondo, the concept behind Appunti per un'Orestiade Africana is based on an analogy which Pasolini draws between the ancient myth narrated in Aeschylus's tragedies and the process of modernization and democratization in contemporary Africa:

Il prossimo film che farò si intitolerà Appunti per un poema sul Terzo Mondo e comprenderà quattro o cinque episodi e uno di questi si svolgerà in Africa e sarà Il padre selvaggio; però non ne sono certo. Può darsi che anziché fare Il padre selvaggio faccia un altro film che mi è venuto in mente, sempre però su questa linea, cioè una Orestiade ambientata in Africa. Ricreerei delle analogie, per quanto arbitrarie e poetiche, e in parte irrazionali, tra il mondo arcaico greco, in cui appare Atena che dà, attraverso Oreste, le prime istituzioni democratiche, e l'Africa moderna.

As the movie itself explains, Pasolini thinks that African tribal civilization is analogous to Greek archaic civilization - that is, to the chthonic, irrational civilization of the Furies that was replaced by Athena's 'rational', Olympian, democratic order. Pasolini maintains that, while the Western world has undergone a transformation from a rural to a 
modern, industrial society in a disastrous way that has completely eliminated any connection with the past, Africa still has the possibility of entering modernity in a more synthetic way that corresponds to the transformation of the Furies into Eumenides at the end of Aeschylus's trilogy - to wit, in a way that would not oppose past and present, archaic and modern civilization, emotion and reason, but would instead integrate them. In other words, whereas in the Western world, and in Italy first and foremost, a type of industrial and technological development without cultural and social progress took place that eliminated any sort of alterity and provoked the monstrous forms of 'cultural genocide' or 'anthropological mutation' which he would still insist upon in the seventies, Pasolini saw Africa in the sixties as a place that could still undergo a kind of development that would not completely erase its own past and traditions. ${ }^{9}$ As Pasolini writes in the 1968-69 'Nota per l'ambientazione dell'Orestiade in Africa':

Le Erinni, che hanno dominato tutta la parte prima della tragedia, in quanto Dee della Tradizione - una tradizione, appunto, selvaggia, grondante sangue e pervasa dal terrore - alla fine, non sono distrutte dalla Dea della Ragione, ma sono trasformate: esse restano sì divinità irrazionali, arcaiche, ma anziché presiedere a sogni atroci, ossessi, degradanti, presiedono alle opere della poesia, della fantasia, del sentimento.

Ora è chiaro che un simile tema di fondo, riferito, oggi, all'Europa, pur restando altamente valido e universale, rischia di essere inattuale. C'è invece un mondo dove quel tema è il tema centrale della storia di oggi: si tratta del mondo africano.

L'Orestiade sintetizza la storia dell'Africa di questi ultimi cento anni: il passaggio cioè quasi brusco e divino, da uno stato 'selvaggio' a uno stato civile e democratico: la serie dei Re, che nell'atroce ristagnamento secolare di una cultura tribale e preistorica, hanno dominato - a loro volta sotto il dominio di nere Erinni - le terre africane - si è come spezzata: la Ragione ha istituito quasi motu proprio istituzioni democratiche. Bisogna aggiungere che il problema veramente scottante e attuale, ora, negli anni Sessanta - gli anni del Terzo Mondo e della Negritudine - è la 'trasformazione delle Erinni in Eumenidi': e qui il genio di Eschilo ha tutto prefigurato. ${ }^{10}$

Two issues interest me in Pasolini's project of using Aeschylus's Oresteia to read the situation of contemporary Africa. The first is the concept of synthesis, which is expressed in Aeschylus's version of the ancient myth and which Pasolini sees as still possible in Africa. Pasolini's insistence on synthesis is striking, given that he usually radically opposes it. The second is the method of analogy, which informs the idea of using an 
ancient Greek myth to read contemporary Africa. Is this operation legitimate? Isn't it an imperialist or exoticizing move that fetishizes and colonizes the other? (While my focus will be on the issue of analogy, the two issues are linked in this case, because one element in the analogy namely the Oresteia - is a model of synthesis.)

Pasolini is well aware of the dangers of analogy, which imposes the author' or filmmaker 's symbolic order onto that of the other represented in the text or movie. This danger is only implied in the quotation just mentioned from Pasolini's interview with Peroni, which acknoweldges the 'poeticity', arbitrariness, and irrationality of the analogy between ancient Greece and contemporary Africa, but it is also made explicit in a passage from the essay on free indirect speech (1965) that deals precisely with the question of how a bourgeois author can have access to characters belonging to other social classes:

La cosa più odiosa e intollerabile, anche nel più innocente dei borghesi, è quella di non saper riconoscere altre esperienze vitali che la propria: e di ricondurre tutte le altre esperienze vitali a una sostanziale analogia con la propria. È una vera offesa che egli compie verso gli altri uomini in condizioni sociali e storiche diverse. Uno scrittore borghese, anche nobile, anche alto, che non sappia riconoscere i caratteri estremi della diversità psicologica di un uomo dalle esperienze vitali diverse dalle sue - e che anzi, creda di impadronirsene cercando delle sostanziali analogie, quasicché altre esperienze che la sua non fossero concepibili - compie un atto che è il primo passo verso forme di difesa dei privilegi e addirittura di razzismo: in tal senso egli non è più libero, ma appartiene edonisticamente alla sua classe: non c'è soluzione di continuità tra lui e un commissario di polizia o un boia dei Lager. ${ }^{11}$

The dilemma expressed by Pasolini is that disavowing radical difference is no less racist than affirming it. The hypothesis that I would like to propose is that Pasolini seeks to deal with this dilemma and with the danger of analogy by constantly shifting back and forth between opposing positions. More specifically, his Appunti per un'Orestiade Africana combines analogy with the medium of film so as to produce a series of Kippbilder between past and present, and in particular between preHellenic Greece and contemporary Africa.

In what sense can one speak of a Kippbild? In the following sense: Appunti constantly shifts between giving a new rendition of Aeschylus's trilogy through the African setting and representing the condition of contemporary Africa through the lens of Aeschylus's play. In particular, 
my hypothesis is that the analogy between Greek past and African present creates a multistable text with different 'aspects'. Sometimes both aspects - the Greek past and the African present - coexist, and these seem to be the moments when the analogy is most strongly confirmed, while at other times the text shifts between past and present or between Greece and Africa and vice versa. In other words, while Appunti sometimes manages to keep both aspects - Greek past and African present together, it often focuses on only one aspect. In fact, both aspects seem to be present together primarily in the moments of transition from one aspect to the other, when the aspect shifts - sometimes at first unnoticeably, to be realized only retroactively. One could therefore say that the whole film is a Kippbild that is successively seen under different aspects - or that the analogy between Greek myth and African present is the Kippbild and that the film unfolds the different aspects, giving shape and body to them at the same time as it guides the gaze of the viewer so that she or he experiences various aspect-changes, which are ultimately perhaps more important than the hypothesis of the analogy's success. Of the many examples that one could give, I will just mention a few which I found particularly interesting.

In its opening credits, in which a geographical map is shown depicting Africa on the right side and another region (difficult to recognize but likely Greece) on the left, on top of which the cover of Pasolini's 1960 translation of the Oresteia is placed, the movie already highlights the doubleness of Pasolini's operation and points to the two aspects that it will create: ancient Greece and Africa. The same image also emphasizes quite strongly Pasolini's own presence, not only implicitly through the cover of his translation of Aeschylus's play but also explicitly through the indication in that he is the writer and director of the movie (Fig. 2). ${ }^{12}$ Pasolini's presence is also strong in the first scene of the actual movie, where we see his figure reflected in a store window while he is filming himself and commenting upon his project of shooting the Oresteia in contemporary Africa (Fig. 3 and Fig. 4). Self-reflexivity characterizes the whole movie, and I will come back to it later.

After the film describes the project of shooting the Oresteia in present Africa and shows images of a 'typical' socialist African nation in its as yet indefinite position between the Chinese/socialist and AngloSaxon/neo-capitalist options, the camera shows an African village while Pasolini's voice-over begins narrating the plot of the Oresteia. The first aspect-change occurs when the voice-over says 'Siamo ad Argo, la città 

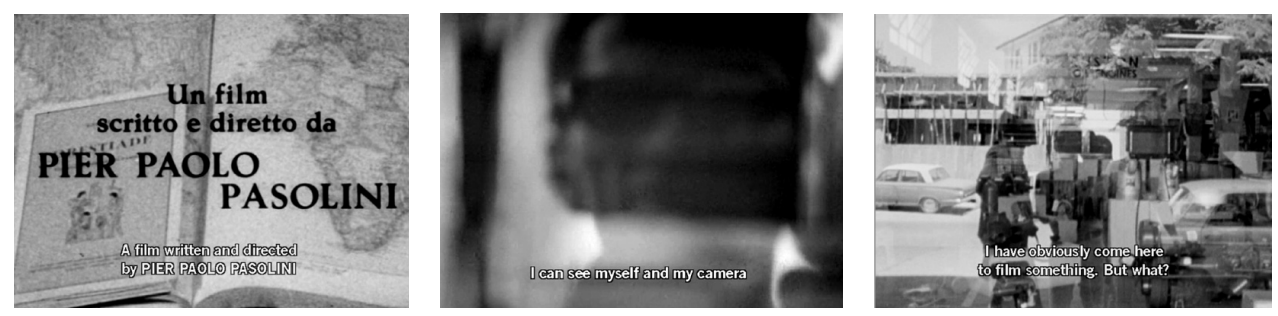

Fig. 2. Film still from Appunti per un'Orestiade africana.

Fig. 3-4. 'Mi sto specchiando con la macchina da presa nella vetrina di un negozio di una città africana. Sono venuto evidentemente a girare, ma che cosa? Non un documentario e non un film. Sono venuto a girare degli appunti per un film: questo

film sarebbe l'Orestiade di Eschilo, da girarsi nell'Africa di oggi, nell'Africa moderna.'
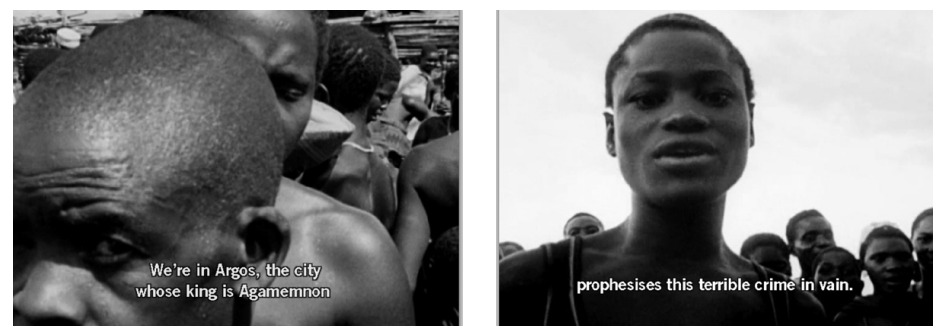

Fig. 5. 'Siamo ad Argo'. Fig. 6. 'Inutilmente Cassandra, la schiava che Agamennone ha portato con sé da Troia, profetizza questo atroce omicidio.'

di cui è re Agamennone, che sta tornando da Troia dove era andato a combattere [...]' (Fig. 5). After creating an overlap between the old Greek town of Argos and a contemporary village in Africa, Appunti begins to move back and forth from present Africa to Greek myth with a certain fusion of the two. When the voice-over mentions the figures of Electra and Orestes alongside images of young Africans who are clearly meant to represent them, another Kippbild is created and young people from contemporary Africa fuse with young characters from the old Greek myth (Fig. 6).

Another aspect-change takes place when the movie deals with Electra's mourning the death of her father. The scene follows the murder of Agamemnon, which Pasolini plans to represent using archive footage from the Biafran wars - in particular, with footage of an execution 


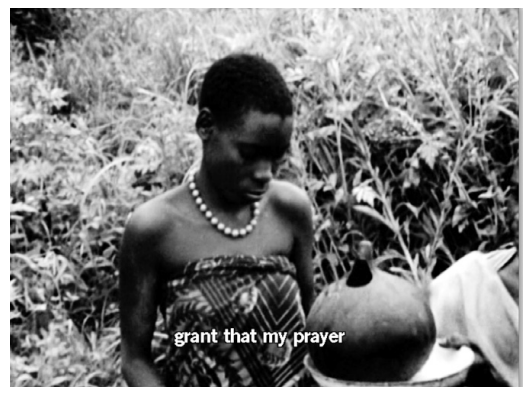

Fig. 7. [ELETTRA] 'Dio dell'Inferno, re dei vivi e dei morti, / fa' che ascoltino questa mia preghiera / gli spiriti che stanno sotto terra, testimoni / terribili dell'assassionio

di mio padre, / e la Terra stessa, madre di tutti noi / che ci ha nutriti e in sé ci raccoglie / a germinare nuove vite - mentre versando / quest'acqua sacra ai morti, io prego mio padre [...].'

shown in all its shocking brutality and violence. While this footage brings the spectator to contemporary Africa, the following scene, through the image of a woman mourning on a grave and the use of the same background music, enacts an aspect-change that takes the spectator back to Aeschylus. Pasolini's voice-over announces that he has found a grave and asked people living nearby to perform the rituals that they usually perform on behalf of the dead; while they do so, the voiceover recites Electra's prayer to the Gods on behalf of Agamemnon from the Oresteia (in Pasolini's own translation). At this point the movie has shifted from contemporary Africa back to the Greek myth (Fig. 7).

A similar oscillation between ancient Greece and contemporary Africa is also present in the five concluding minutes of the movie, which first describe the transformation of the Furies into Eumenides, symbolizing the synthesis between past and present that Pasolini desires for Africa, and then show African peasants working the fields against the musical background of Soviet revolutionary songs (Fig. 8). In these final minutes the film moves from the presence of both the Greek past and present (when Aeschylus's verses are read against the images of the Eumenides) to a shift between past and present. And the conclusion is emphatically about the present - about Africa and its possibility of acting out the synthesis that has not taken place in the West.

The end of the movie suggests that - at least in Africa - a synthesis is still possible and looks at the future with hope and openness. As Pasolini acknowledges, the film's optimistic vision is influenced by 


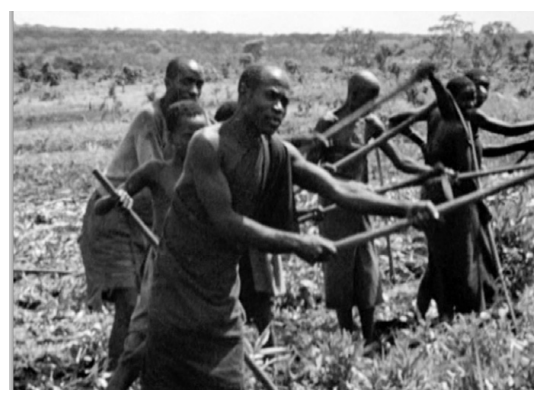

Fig. 8. 'Ecco gli ultimi appunti per una conclusione. Il nuovo mondo è instaurato. Il potere di decidere il proprio destino è, almeno formalmente, nelle mani del popolo. Le antiche divinità primordiali coesistono con il nuovo mondo della ragione e della libertà. Ma come concludere? Ebbene, la conclusione ultima non c'è, è sospesa. Una nuova nazione è nata, i problemi sono infiniti. Ma i problemi non si risolvono, si vivono. E la vita è lenta. Il procedere verso il futuro non ha soluzioni di continuità. Il lavoro di un popolo non conosce né retorica né indugi. Il suo futuro è nella sua ansia di futuro. E la sua ansia è una grande pazienza.'

Léopold Sédar Senghor's reconciliatory 'ideology' and his idea that the new Africa cannot but be a synthesis between the modern, independent, free Africa and the old Africa. ${ }^{13}$ Giovanna Trento has argued that, in addition to Senghor's influence, the optimism of Pasolini's project is also due to the fact that it actually stemmed from the 1959-60 translation of the Oresteia and was first conceived in tight proximity with the decolonization process. ${ }^{14}$ Yet I would also like to argue that this very idea of synthesis is at the same time challenged in the movie itself - first of all by the idea that a 'final conclusion' is actually missing and is 'sospesa', suspended: 'sospesa' is a very loaded term in Pasolini, and here it expresses the idea that synthesis is a hope rather than a certainty. ${ }^{15}$ Furthermore, and perhaps most importantly, the ideas of analogy and synthesis are questioned by two scenes in which the movie enacts a veritable mise en scène of an aspect-change, showing the perspective of some African students in Italy who challenge the very legitimacy of the project for an African Oresteia.

These two scenes perform another type of aspect-change, not in the sense of moving from ancient Greece to contemporary Africa as we have seen so far, but in that of moving from the filmic interpretation that the author-Pasolini proposes of Africa, through the lens of the Oresteia and vice versa, to the viewing of the same images by a group 

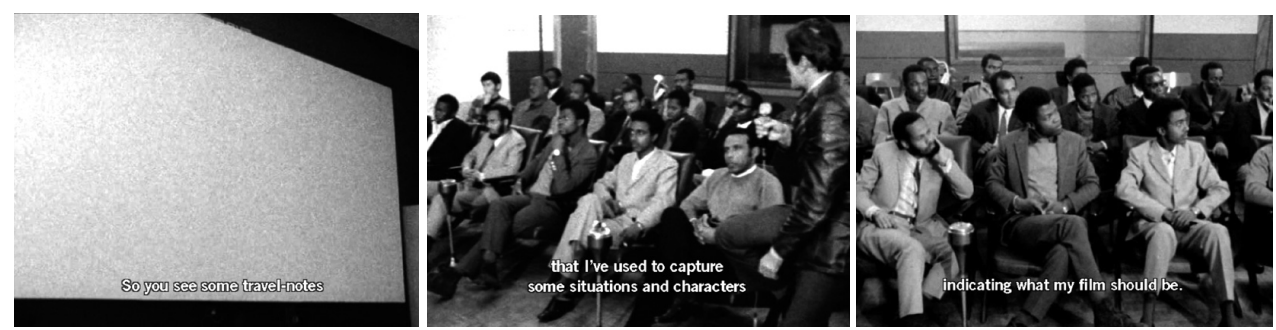

Fig. 9. [PASOLINI] 'Allora voi avete visto degli appunti, delle note di viaggio che mi sono servite a bloccare alcune situazioni, alcuni personaggi di quello che dovrebbe essere il mio film sull'Orestiade.'

of African students, who now give their own reading of the material. What is particularly interesting about these two scenes is that, in beginning by displaying the screen onto which Pasolini's filmic notes for his African project were projected and then moving to the African students watching those notes, the movie enacts a mise en abime of the phenomenon of Aspektwechsel itself.

The first of these two scenes takes place after some images of a school in the Tanzanian town of Kigoma have been shown and Pasolini's voice-over has commented that African students are 'obedient, passive, and humble': 'Gli studenti africani di fronte al sapere che gli si presenta - sembra - ancora come un dono, come una concessione, sono obbedienti, passivi e umili.' Then a sudden shift of perspective is staged: we have moved from a classroom in Africa to a classroom in Rome, and we realize that a group of African students have been shown the same footage that we had seen earlier (Fig. 9). Pasolini, now in front of the camera, explains his project again and asks the students whether they think that it should relate to Africa in the 1970s or in the 1960s. Rather than being 'passive and obedient', as African students are said to be in Africa, these students show quite a strong resistance towards Pasolini's project. They indicate that, from their perspective, the analogy between ancient Greece and contemporary Africa does not really work. For instance, one student argues that Pasolini's concept of Africa is too generic and homogenizing and that Africa is a vast continent that cannot be treated as though it were one single nation, while another student challenges the legitimacy of the way in which Pasolini speaks of tribalism in Africa, and another does not agree that the democracy that has recently developed in Africa can be considered a genuine form of 
democracy. It is an interesting dialogue because, although Pasolini insists on his idea and tries to justify it, the African students' perspective on the project is sceptical and brings to light its problematic aspects (of which Pasolini is clearly aware and which he wants to show). The first scene ends with the following exchange:

$1^{\circ}$ STUDENTE: Io non sono pratico del film, però non ne vedo la connessione.

PASOLINI: Siete tutti d'accordo con lui? O c'è qualcuno che, invece, vede una connessione, una possibilità di connessione?

$2^{\circ}$ STUDENTE Secondo me, formalmente, l'idea si può anche verificare ... solo che rimarrà un po'... qualcosa di immaginativo. Cioè nella realtà sarà abbastanza difficile, almeno nella realtà odierna. Forse se lei ambienta il film negli anni Sessanta e Cinquanta ... però, il legame si può trovare.

The second scene with the African students takes place towards the end of the film, right after the movie has finished recounting (and showing) the absolution of Orestes by the Aeropagos (the court founded by Athena in Athens). It opens in the same way as the first scene by highlighting the Aspekwechsel towards the students' perspective, but here Pasolini asks the students whether they think that there is some analogy between Orestes' going to Athens and their own going to study in the West. In comparison with the previous scene, the students now seem less resistant but continue to express unease towards the analogy between the Greek myth and contemporary Africa. I will quote from the concluding moment of the scene, when Pasolini asks how it would be possible to represent the Furies' transformation into Eumenides:

PASOLINI: Questo mi porta alla seconda domanda. Il film finisce con la trasformazione delle Furie in Eumenidi, e questa è una specie di sintesi. Come si potrebbe rappresentare la trasformazione delle Furie in Eumenidi? $1^{\circ}$ STUDENTE: Non so, questa trasformazione così dall'uno all'altro, non credo che si possa ottenere completamente; cioè ... esiste sia l'uno che l'altro. Esisterà sempre, secondo me, perché l'Africano è fondamentalmente un uomo così ... Possiede una vita interiore molto profonda, uno spirito molto profondo; quindi quando lei parla di Furie che si trasformano in Eumenidi, probabilmente potranno crearsi delle Eumenidi senza che le Furie spariscano - che spariscano completamente credo che sarà abbastanza difficile.

Both Maurizio Viano and Luca Caminati highlight that, through its self-reflexive insistence on Pasolini's presence as filmmaker, which - as 
we have seen - is made explicit from the credits and the very first scene onward, and through the scenes with the African students, the movie deconstructs the colonializing move of attempting to use the Greek myth as a universal model to look at contemporary Africa. In particular, Viano writes that the debates with the African students function as 'antidote' against cultural colonialism, ${ }^{16}$ and Caminati argues that the very presence of the author represents a form of participatory ethnography and destabilizes the idea that the film's narration is a vehicle of scientific information. ${ }^{17}$

I agree with Viano and Caminati and I would also add that, by opening in the same fashion and directing the spectator's attention towards the fact that an aspect-change is taking place, both scenes with the African students not only indicate that what was shown was Pasolini's perspective, which differs from that of the students, but also bring to the fore the fact that the spectators also have a position from which they look at the film. Moreover, the last exchange with the student quoted above also challenges the idea of dialectic and synthesis, which sustains the whole project and is also proposed in the final scene. We could say that here the student proposes yet another Kippbild: not an analogy between current Africa and the Greek past as Kippbild - one single object, a universal structure or myth of which Greek antiquity and twentieth-century Africa are but two aspects; instead, Africa in the process of decolonization as a Kippbild that can be seen under different but contradictory aspects between which there is no synthesis: one part of the Furies is transformed into the Eumenides and opens up to the future, but another part resists that transformation and keeps a connection to the past.

With the students' voices Pasolini also includes the possibility that the project is flawed and could fail. Interestingly, the position of the final student to speak in a scene corresponds to what Pasolini usually thinks and, for example, expresses in the passages quoted at the beginning of my paper: that no dialectic or synthesis is possible, but only coexistence and stratification. In fact, Pasolini's play Pilade, a continuation of the Oresteia, envisages precisely that half of the Eumenides will turn back into Furies. ${ }^{18}$ Not only does the Athenian synthesis of the Oresteia ultimately fail there, but the play Pilade also proposes the idea that the failure of political projects may be preferable to their success. In an essay on La Divina Mimesis and Petrolio, I have argued that La Divina Mimesis, which presents itself as an unfinished text, stages its 
own failure. Referring to Lee Edelman's provocative book No Future: Queer Theory and the Death Drive, ${ }^{19}$ I have interpreted such a staging of failure as a political and artistic gesture against the violence of heteronormativity and the linear sense of progress imposed by neo-capitalism and its aesthetics. ${ }^{20}$ Pasolini's film project is not as radical as the later Divina Mimesis in negating its own premises; in fact, as Carla Benedetti has argued, the form of the project conveys a mode of intentionality and potentiality. ${ }^{21}$ But ultimately it seems to me that, from this perspective as well, Appunti per un'Orestiade africana is a multistable text: if we do not get the sense that Pasolini really wants to, or ought to, complete the planned Orestiade, it is also because Appunti already goes a long way in showing it. At the same time, by including the African students' critical perspective and formally emphasizing it in terms of an aspect-change, Appunti per un'Orestiade africana also challenges the project's legitimacy. Rather than success or failure, the point seems to be to problematize the operation through all the Kippbilder created and to keep the possibility of an African Oresteia in suspense.

Davide Zoletto has recently argued that Pasolini, in highlighting the constructed character of categories, implies the possibility of constructing different ones and that, by indicating with pedagogical and theoretical rigour that he cannot avoid constructing his own personal view of Africa, he affords the viewer the possibility not only of recognizing constructions as such, but also of constructing new ones. ${ }^{22} \mathrm{I}$ would add that the operation remains unstable and appears 'risky' and paradoxical, and that it is questionable whether it can succeed so unequivocally in its emancipatory aim. After all, if it suggests its own failure, that means that it also contradicts its optimistic outlook on Africa's future. Furthermore, if the African students end up saying what Pasolini usually holds - the impossibility of synthesis - should we view Pasolini's movie on Africa as a clever, cunning strategy to restate his own opinion through the students' voices by manipulating them into expressing his own position, or should we rather emphasize that Pasolini avoids the error of presuming that he knows what people with different experiences really think, but instead always keeps his own position clear and situates himself as a white, Western, bourgeois filmmaker? And the question would also remain whether the act of acknowledging - and, in this case, even highlighting - the constructed and situated character of one's own reading of the 'other' would suffice to legitimize the operation itself. 
1 Pier Paolo Pasolini, 'Le ceneri di Gramsci', in Tutte le poesie, ed. by Walter Siti, 2 vols (Milan: Mondadori, 2003), i, p. 820.

2 Franco Fortini, 'Le poesie italiane di questi anni', Il Menabò, 2 (1960), pp. 10342 (p. 130); see also Franco Fortini, Attraverso Pasolini (Turin: Einaudi, 1993), pp. 21-37 (p. 22), and Hervé Joubert-Laurencin, Pasolini: portrait du poète en cineaste (Paris: Cahiers du Cinéma, 1995), pp. 45-48.

3 See also Robert S.C. Gordon, Pasolini: Forms of Subjectivity (Oxford: Oxford University Press, 1996), in which it is argued that the most profound significance of Pasolini's trope of contradiction lies in its resistance to coherent closure and in the 'movement, discontinuity, provisionality' that it enacts (p. 185).

4 In Sergio Arecco, Pier Paolo Pasolini (Rome: Partisan, 1972), p. 69; see also Joubert-Laurencin, Pasolini, pp. 209-10.

5 Pier Paolo Pasolini, Il sogno del centauro, in Saggi sulla politica e sulla società, ed. by Walter Siti and Silvia De Laude (Milan: Mondadori, 1999), pp. 1461 and 1474. On Pasolini's emphasis on the inadequacy of Hegelian dialectics, see Silvestra Mariniello, 'Temporality and the Culture of Intervention', boundary 2, 22.3 (1995), pp. 111-39.

6 Ludwig Wittgenstein, Philosophische Untersuchungen/Philosophical Investigations, trans. by G.E.M. Anscombe (Oxford: Blackwell, 1953), pp. 194-194a.

7 See Severin Schroeder, 'A Tale of Two Problems: Wittgenstein's Discussion of Aspect Perception', in Mind, Method, and Morality: Essays in Honour of Anthony Kenny, ed. by J. Cottingham and P.M.S. Hacker (Oxford: Oxford University Press), 2010, pp. 352-72, esp. p. 356. My understanding of multistable figure draws especially on the following works by Sara Fortuna: Wittgensteins Philosophie des Kippbildes: Aspektwechsel, Ethik, Sprache (Vienna: Turia + Kant, 2012) and A un secondo sguardo: Il mobile confine tra percezione e linguaggio (Rome: manifestolibri, 2003). Sara Fortuna and I have dealt with multistable figures and aspect-changes in our reading of Dante's Paradiso: 'Dante after Wittgenstein: "Aspetto", Language, and Subjectivity from Convivio to Paradiso', in Dante's Plurilingualism: Authority, Knowledge, Subjectivity, ed. by Sara Fortuna, Manuele Gragnolati, and Jürgen Trabant (Oxford: Legenda, 2010), pp. 223-48. See also the essays contained in Multistable Figures: On the Critical Potentials of Ir/Reversible Aspect-Seeing, ed. by Christoph F. E. Holzhey (Vienna: Turia + Kant, forthcoming 2012), as well as, in this volume, Christoph Holzhey's essay “"La vera Diversità": Multistability, Circularity, and Abjection in Pasolini's Pilade' and Luca Di Blasi's 'One Divided by Another: Split and Conversion in Pasolini's San Paolo'.

8 On Pasolini's translation of the Oresteia, see Massimo Fusillo, La Grecia secondo Pasolini (Rome: Carocci, 2007), pp. 146-62.

9 See Giacomo Marramao, 'A partire da Salò: corpo e potere nell'opera di Pasolini', aut aut, 345 (Jan.-Mar. 2010), pp. 116-23; Giulio Sapelli, Modernizzazione senza sviluppo: Il capitalismo secondo Pasolini (Milan: Bruno Mondadori, 2005). I have also dealt with Pasolini's concept of 'cultural genocide' as erasure 
of alterity in 'Pier Paolo Pasolini's Queer Performance: La Divina Mimesis between Dante and Petrolio', in Corpus xxx: Pasolini, Petrolio, Salò, ed. by Davide Messina (Bologna: CLUEB, 2012), pp. 134-64

10 Pier Paolo Pasolini, Per il cinema, ed. by Walter Siti and Frabco Zabaglio, 2 vols (Milan: Mondandori, 2001), I, pp. 1199-1200.

11 Pier Paolo Pasolini, 'Intervento sul discorso libero indiretto', in Empirismo eretico, in Saggi sulla letteratura e sull'arte, ed. by Walter Siti and Silvia De Laude, 2 vols (Milan: Mondadori, 1999), I, pp 1356-57.

12 Quotations from the Appunti per un'Orestiade africana will be taken from Pasolini, Per il cinema, I, pp. 1175-96.

13 'Il mio film sarà molto datato. Abbiamo visto: 1960, l'anno in cui la maggior parte degli Stati africani in poco tempo recuperano un ritardo si può dire di secoli, di millenni, raggiungendo l'indipendenza, la democrazia. Anche la conclusione non può che essere datata, cioè non può che riferirsi alla ideologia africana di quegli anni, che ha avuto probabilmente il suo simbolo in Senghor, il presidente del Senegal: cioè l'idea che l'Africa nuova, l'Africa del futuro, non può essere che una sintesi dell'Africa moderna, indipendente, libera, e dell'Africa antica' (Per il cinema, I, p. 1194).

14 Giovanna Trento, Pasolini e l'Africa: Panmeridionalismo e rappresentazione dell'Africa postcoloniale (Milan: Mimesis, 2010), pp. 179-99. On the optimistic character of Pasolini's project, see also Fusillo, La Grecia secondo Pasolini, 17884.

15 See Christoph Holzhey's essay in this volume and Hervé Joubert-Laurencin, 'Pasolini-Barthes: Engagement et suspension de sens', Studi Pasoliniani, 1 (2007), pp. 55-67.

16 Maurizio Viano, A Certain Realism: Making Use of Pasolini's Film Theory and Practice (Berkeley: University of California Press, 1993), p. 252.

17 Luca Caminati, Orientalismo eretico: Pier Paolo Pasolini e il cinema del terzo mondo (Milan: Bruno Mondadori, 2007), pp. 69-71.

18 See Christoph Holzhey's paper in this volume.

19 Lee Edelman, No Future: Queer Theory and the Death Drive (Durham: Duke University Press, 2004).

20 See Gragnolati, 'Pier Paolo Pasolini's Queer Performance'.

21 Carla Benedetti, Pasolini contro Calvino: Per una letteratura impura (Turin: Bollati Boringhieri, 1998), pp. 158-70 (p. 163); see also Antonio Tricomi, Sullopera mancata di Pasolini: Un autore irrisolto e il suo laboratorio (Rome: Carocci, 2005).

22 Davide Zoletto, 'Pasolini, l'Africa e due scene di insegnamento', aut aut, 345 (Jan.-Mar. 2010), pp. 20-27. 
Manuele Gragnolati, 'Analogy and Difference: Multistable Figures in Pier Paolo Pasolini's Appunti per un'Orestiade Africana', in The Scandal of Self-Contradiction: Pasolini's Multistable Subjectivities, Geographies, Traditions, ed. by Luca Di Blasi, Manuele Gragnolati, and Christoph F. E. Holzhey, Cultural Inquiry, 6 (Vienna: Turia + Kant, 2012), pp. 119-33 <https://doi.org/10.37050/ci-06_07>

\section{REFERENCES}

Arecco, Sergio, Pier Paolo Pasolini (Rome: Partisan, 1972)

Benedetti, Carla, Pasolini contro Calvino: Per una letteratura impura (Turin: Bollati Boringhieri, 1998)

Caminati, Luca, Orientalismo eretico: Pier Paolo Pasolini e il cinema del Terzo Mondo (Milan: Bruno Mondadori, 2007)

Edelman, Lee, No Future: Queer Theory and the Death Drive (Durham, NC: Duke University Press, 2004) <https://doi.org/10.1215/9780822385981>

Fortini, Franco, Attraverso Pasolini (Turin: Einaudi, 1993)

Fortuna, Sara, $A$ un secondo sguardo: Il mobile confine tra percezione e linguaggio (Rome: manifestolibri, 2003)

—Wittgensteins Philosophie des Kippbildes: Aspektwechsel, Ethik, Sprache (Vienna: Turia + Kant, 2012)

Fortuna, Sara, Manuele Gragnolati, and Jürgen Trabant, eds, Dante's Plurilingualism: Authority, Knowledge, Subjectivity (Oxford: Legenda, 2010)

Fusillo, Massimo, La Grecia secondo Pasolini: Mito e cinema (Rome: Carocci, 2007)

Gordon, Robert S. C., Pasolini: Forms of Subjectivity (Oxford: Oxford University Press, 1996)

Gragnolati, Manuele, 'Pier Paolo Pasolini’s Queer Performance: La Divina Mimesis between Dante and Petrolio', in Corpus xxx: Pasolini, Petrolio, Salo, ed. by Davide Messina (Bologna: CLUEB, 2012), pp. 134-64

Holzhey, Christoph F. E., ed., Multistable Figures: On the Critical Potentials of Ir/Reversible AspectSeeing (Vienna: Turia + Kant, 2012)

Joubert-Laurencin, Hervé, Pasolini: Portrait du poète en cinéaste (Paris: Cahiers du Cinéma, 1995)

Mariniello, Silvestra, 'Temporality and the Culture of Intervention', boundary 2, 22.3 (1995), pp. 111-39<https://doi.org/10.2307/303725>

Marramao, Giacomo, 'A partire da Salò: corpo e potere nell'opera di Pasolini', aut aut, 345 (Jan.Mar. 2010), pp. 116-23

Pasolini, Pier Paolo, Per il cinema, ed. by Walter Siti and Franco Zabagli, 2 vols (Milan: Mondadori, 2001)

__ Saggi sulla politica e sulla società, ed. by Walter Siti and Silvia De Laude (Milan: Mondadori, 1999)

Tutte le poesie, ed. by Walter Siti, 2 vols (Milan: Mondadori, 2003)

Sapelli, Giulio, Modernizzazione senza sviluppo: Il capitalismo secondo Pasolini (Milan: Bruno Mondadori, 2005)

Schroeder, Severin, 'A Tale of Two Problems: Wittgenstein's Discussion of Aspect Perception', in Mind, Method, and Morality: Essays in Honour of Anthony Kenny, ed. by J. Cottingham and P.M.S. Hacker (Oxford: Oxford University Press, 2010), pp. 352-72

Trento, Giovanna, Pasolini e l'Africa, l'Africa di Pasolini: Panmeridionalismo e rappresentazioni dell'Africa postcoloniale (Milan: Mimesis, 2010) 
Viano, Maurizio, A Certain Realism: Making Use of Pasolini's Film Theory and Practice (Berkeley: University of California Press, 1993)

Wittgenstein, Ludwig, Philosophische Untersuchungen/Philosophical Investigations, trans. by G.E.M. Anscombe (Oxford: Blackwell, 1953)

Zoletto, Davide, 'Pasolini, l'Africa e due scene di insegnamento', aut aut, 345 (Jan.-Mar. 2010), pp. 20-27 